\title{
Celtic Christianity in the Victorian Era: An Exploration Through Literature
}

\begin{abstract}
:
In the 1880s and 1890s, the British Isles-Ireland especially-experienced a Celtic Literary Revival. Drawing on both history and religion, this revival focused on aspects of old Celtic spirituality and how their beliefs were intertwined with the natural world around them. While not everyone was sympathetic to this sense of spirituality and nostalgia, the revival did gain traction amongst many authors of the time. Using the works of influential writers like William Butler Yeats and the Rhymers Club, this paper seeks to explore how Celtic spirituality was being rediscovered and interpreted during the late Victorian period.
\end{abstract}


As T.W. Rolleston writes, "The past may be forgotten, but it never dies," something that is especially true when considering the Celtic Revival in the Victorian period. ${ }^{1}$ The Victorian Era in the British Isles was a period that, among other things, brought with it changing notions of history, ideals, and politics, along with art and literature; this statement being considerably accurate if one considers the Celtic Revival and all it entailed. ${ }^{2}$ Bringing with it a surge of nationalism in Celtic countries, opinions differed across the British Isles on how to interpret their Celtic pasts. ${ }^{3}$ On the one hand, this increase of spirituality and nationalism bolstered the Celtic, especially Irish, senses of identity and resulted in nationalist movements like the Gaelic League, especially amongst Catholic priests and nuns. ${ }^{4}$ On the other hand, however, some of the English maintained the inferiority of the Celts and rejected the revival as a whole. ${ }^{5}$ Nevertheless, the Celtic revival became a widespread movement across the British Isles, with one of the ways in which this manifested itself being in the literary world of authors and poets, Celtic or otherwise. ${ }^{6}$ In this essay I will argue that the Celtic literary revival of the 1880 s and 1890s was inspired in large part by the resurrection of Celtic spirituality ideals by looking at the poems of William Butler Yeats, Lionel Johnson and the Rhymer's Club, as well as Matthew Arnold's work in order to show how this movement grew due to Celtic spirituality.

For a civilization or religion to have a revival, by the very definition of the word there first has to be the notion of a shared past in order to have something to return to. What made

\footnotetext{
${ }^{1}$ T.W. Rolleston, Myths and Legends Series: Celtic (London: Bracken Books, 1985.), ix.

${ }^{2}$ Ian Bradley, Celtic Christianity: Making Myths and Chasing Dreams, (Edinburgh: Edinburgh University Press, 1999.), 119.

${ }^{3}$ Bradley, Celtic Christianity, 119.

4 Timothy G. McMahon, Grand Opportunity: The Gaelic Revival and Irish Society, 1893-1910 (Syracuse, New York: Syracuse University Press, 2008.), 34.

${ }^{5}$ Bradley, Celtic Christianity, 119.

${ }^{6}$ Bradley, Celtic Christianity, 119.
} 
that civilization unique, why was their time period so celebrated, what does the present read into the past in order to want to bring the past back; all of those factors are relevant when considering the Celtic revival in the British Isles. The first question, however, is the background: what exactly was Celtic Christianity, and what made it different from other forms of Christianity in the past? Exploring the context of Celtic Christianity will be useful for understanding the linkages between the Victorian Celts and their past.

The Celtic variant of Christianity is an old one; author James P. Mackey argues that the Celts were one of the quickest and earliest people to adopt Christianity. ${ }^{7}$ In the early centuries the Celts extended across most of Northern Europe, but were gradually pushed back to the areas in which they inhabited in the Victorian period: Scotland, Wales, Brittany, and Ireland. ${ }^{8}$ The Celts, being that for much of their time they were confined to the British Isles, developed a Christianity that was unlike that of mainland Europe. ${ }^{9}$ For one, they had a difference sense of God; God was everywhere, in everything. ${ }^{10}$ In relation to this, that meant the Celts had a special relationship with nature: animals, plants, even inanimate objects like rocks and wind, all were said to be divinely influenced by the presence of God. ${ }^{11}$ Secondly, they did not just abandon their previous pagan and druidic beliefs with the arrival of Christianity; they incorporated their religion as a mixture of the two, seeing no sense in completely replacing one set of beliefs with another. ${ }^{12}$ Lastly, women also played a much greater role in Celtic spirituality than in other

\footnotetext{
7 James P. Mackey, “Introduction: Is There A Celtic Christianity?” An Introduction to Celtic Christianity, ed. James P. Mackey, (Edinburgh: T\&T Clark, 1995), 2.

${ }^{8}$ Richard H. Schmidt, God Seekers: Twenty Centuries of Christian Spiritualties (Grand Rapids, Michigan: William B. Eerdmans Publishing Company, 2008), 59.

${ }^{9}$ Schmidt, God Seekers, 59.

10 Mackey, "Introduction," 13.

${ }^{11}$ Schmidt, God Seekers, 60.

${ }^{12}$ Schmidt, God Seekers, 60.
} 
Christian variants, and missionary activity was practiced to spread the word of God to other peoples. ${ }^{13}$ Altogether, these factors came together to create a truly unique and characteristic Christianity in the Celtic lands.

Firstly, to show how the characteristics of Victorian era poetry were a revival of those from the Celtic past, it is useful to show an example of literature from the time period of early Celtic Christianity. The Hymn of Saint Patrick, or Saint Patrick's Breastplate is a very good example that shows ideas of Celtic spirituality. The exact date in which this hymn was written vary; according to legend it was sung by Saint Patrick to act as protection against a group of bandits, which would date it to sometime in the fifth century, but the generally agreed upon speculation is that it was written sometime, perhaps centuries, after Patrick's death. ${ }^{14}$ Nevertheless, it was written centuries before the Victorian era, and contains allusions to not only the beliefs of Saint Patrick, but of Celtic spirituality as a whole. A hymn rather than a poem or story, The Hymn of Saint Patrick concerns itself with binding oneself to God and the Trinity, asking for His guidance in life and protection from false prophets, witches, and heretics. ${ }^{15}$ There is also a strong emphasis on Godly virtues and good behaviour, as well as a rejection of temptation and earthly vices. ${ }^{16}$ However, the most useful portions of this hymn for the purposes of this paper are the fourth verse:

I rise and bind to myself today the power of heaven, the sun's brilliance, the moon's radiance,

\footnotetext{
${ }^{13}$ Schmidt, God Seekers, 59-60.

${ }^{14}$ Schmidt, God Seekers, 62.

${ }^{15}$ Schmidt, God Seekers, 65-67.

${ }^{16}$ Schmidt, God Seekers, 65-67.
} 
the splendor of fire, the flashing of lightning, the speed of wind, the depths of sea, the immovable earth, and solid rock. ${ }^{17}$

And the seventh verse:

Christ with me, Christ before me, Christ behind me, Christ within me, Christ beneath me, Christ above me, Christ to my right, Christ to my left, Christ in my lying, in my sitting, in my rising, Christ in the heart of all who think of me, Christ in the mouth of all who speak of me, Christ in the eye of all who see me, Christ in the ear of all who hear me. ${ }^{18}$

These verses of the hymn illustrate two important aspects of Celtic Christianity. The fourth verse emphasizes the natural world; Saint Patrick is continually calling to multiple forces of nature, the sea, the wind, fire, and tying them to religion, in this case Christ. ${ }^{19}$ The seventh verse echoes much of the previous argument on where God is found in Celtic spirituality. ${ }^{20}$ Here, Patrick finds evidence of God everywhere: surrounding his physical being in the natural world, within the senses of the people he meets, even within himself. ${ }^{21}$ Both of these verses, it would seem, are arguably the most influential for the Victorian era because these ideas show up frequently in the literary revival, especially amongst poets.

\footnotetext{
${ }^{17}$ Schmidt, God Seekers, 66.

${ }^{18}$ Schmidt, God Seekers, 67.

${ }^{19}$ Schmidt, God Seekers, 66.

${ }^{20}$ Mackey, "Introduction," 13

${ }^{21}$ Schmidt, God Seekers, 67.
} 
One of these famous poets was William Butler Yeats (1865-1939), an Irishman. Many of his works were heavily steeped in Irish and Celtic folklore and history, from his poems to his longer works; his The Celtic Twilight especially, a collection of poems and part autobiography, was inspired by his homeland, oral traditions, and stories he collected of Celtic legends and spirituality. ${ }^{22}$ Yeats thought -and accomplished-- that he could preserve this Celtic folklore tradition, highlighting the pre-Christian pagan and druidic beliefs, and in some cases, how they influenced the Christianity that mixed with them. ${ }^{23}$

Yeats' poetry did not just have Celtic folklore, nature, and religious significances, some of his poems also had contemporary roots in the current Irish nationalism movements. One of them, titled To Ireland In The Coming Times, reads as an ode to Ireland, Yeats' dedication to his country. Published in 1892, Yeats describes himself as a "True brother of a company that sang,/ to sweeten Ireland's wrong," saying that "While I still may, I write for you/ the love I lived, the dream I knew."24 While not seemingly focused on religious significance, this poem does mention both God and the Celtic pagan past, though the pre-Christian past seems to take the forefront here. For example, Yeats writes about Ireland “whose history began/Before God made the angelic clan." 25 In another verse, Yeats describes Ireland as being "a druid land." 26 This is especially true of Celtic Christianity, as again, they kept their traditional beliefs alongside

\footnotetext{
${ }^{22}$ William Butler Yeats, The Celtic Twilight, intro. by Kathleen Raine, (Gerrards Cross, England: Colin Smythe Limited, 1981.), 7.

${ }^{23}$ Robert Welch, Irish Writers and Religion, ed. Robert Welch (Gerrards Cross, Buckinghamshire: Collin Smythe, 1992), $x$.

${ }^{24}$ William Butler Yeats, "To Ireland in the Coming Times," William Butler Yeats: Selected Poems and Four Plays, $4^{\text {th }}$ ed., ed. M.L. Rosenthal (New York: Scribner Paperback Poetry, 1996), 18-19.

${ }^{25}$ Yeats, "To Ireland in the Coming Times," 18.

${ }^{26}$ Yeats, "To Ireland in the Coming Times," 19.
} 
their new ones. ${ }^{27}$ Their history did not just began with the arrival of Christianity, Yeats seems to argue here, but the Irish had a valid past before that as well.

Yeats carries on with this natural and Celtic past in his other poems, such as with the Dedication of 'Irish Tales,' of which I've included excerpts of verses one, three, and six (the last verse):

There was a green branch hung with many a bell When her own people ruled in wave-worn Eri, And from its murmuring greenness calm of faery --A Druid kindness-- on all hearers fell.

Ah, Exiles wandering over many seas, Spinning at all times Eri's good to-morrow, Ah, World-wide Nation, always growing sorrow, I also bear a bell branch full of ease.

A honied ringing, under the new skies, They bring you memories of old village faces, Cabins gone now, old well-sides, old dear places, And men who loved the cause that never dies. ${ }^{28}$

This poem seems to forgo any modern notion of God in favor of being set completely in the revival of the Celtic past. Spiritually, this poem uses the old Irish name of Ireland, translated as Erie, and likely what Yeats means when he writes 'Eri. ${ }^{29}$ Being used in a feminine form within the poem, it is arguable that by doing so Yeats evokes the name of the divine Celtic goddess Ériu, one of a triad of goddesses and the one most associated with Ireland, even today. ${ }^{30}$ Not

\footnotetext{
27 Schmidt, God Seekers, 60.

${ }^{28}$ William Butler Yeats, "Dedication To 'Irish Tales,'” The Book of the Rhymer's Club (London: Elkin Matthews, 1892), 54-55.

${ }^{29}$ The Editors of the Encyclopaedia Britannica, "Ireland," Encyclopaedia Britannica, last modified April 2018, accessed April 21 ${ }^{\text {st }}, 2018$. https://www.britannica.com/place/Ireland.

30 Rolleston, Myths and Legends Series: Celtic, 132.
} 
only is Ériu a personification of Ireland itself, but she is both a fertility and war goddess and is overall a prominent figure in Celtic mythology. ${ }^{31}$ Furthermore with Ériu, in combination with the druids and faeries that he writes about, Yeats shows how the pagan and Christian beliefs of the Celtic people are intertwined, and how the ancient Celts abided by both their beliefs together. ${ }^{32}$ That Yeats chooses to make the conscious decision to use the word 'Eri,' instead of Ireland, I would argue, is another way in which he highlights the Irish traditional past over the present. He legitimizes Celtic spirituality by bringing these beliefs to the forefront in his literature.

Yeats was not the only poet of his time to write about Ireland and the Celtic past and spirituality, in fact there was a whole club of poets dedicated in part to this subject. Called the Rhymer's Club, they were a predominantly London based club, of which the Irish Yeats was a member along with others, including Ernest Rhys, Francis Thompson, and John Davidson. ${ }^{33}$ Operating most actively from 1891 to 1894 , the Rhymer's Club consisted of twelve loosely collaborating poets who released two anthologies of poetry, and were said to be some of the best poets of the decade. ${ }^{34}$ Of these collected poems, many of them were said to have a Celtic tinge or flavour to them, inspired by the Celtic literary revival of the period. ${ }^{35}$

\footnotetext{
${ }^{31}$ Miranda Green, The Gods of the Celts (Gloucester: Alan Sutton, 1986.), 101.

${ }^{32}$ Schmidt, God Seekers, 60.

${ }^{33}$ Daniel G. Williams, "Celticism," Oxford Twenty-First Century Approaches to Literature: Late Victorian Into Modern, ed. Laura Marcus, Michele Mendelssohn, and Kirsten E. Shepherd-Barr (Oxford: Oxford University Press, 2016), 75.

${ }^{34}$ Derek Stanford, Three Poets of the Rhymer's Club: Ernest Dowson, Lionel Johnson, John Davidson (Cheadle: Carcanet Press, 1974), 26-27.

${ }^{35}$ Williams, "Celticism," 75-76.
} 
Besides Yeats, another of these influential Rhymer's Club members was Lionel Johnson (1867-1902). Interestingly enough, Johnson himself was an Englishman, though later in his life he would self-identify as an Irishman. ${ }^{36}$ Johnson rejected English Protestantism, finding himself more of a home in the Catholic spiritualties of Ireland. ${ }^{37}$ He also identified more with the sense of going back to an olden time or perspective, just like many people associated with the Celtic peoples at this time. ${ }^{38}$ While Johnson only wrote a few books of poetry before his early death, some of his poems did deal quite heavily in Irish and Celtic themes. Among them is his 1887 poem Celtic Speech:

Never forgetful silence fall on thee, Nor younger voices overtake thee, Nor echoes from thine ancient hills forsake thee;

Old music heard by Mona of the sea:

And where with moving melodies there break thee Pastoral Conway, venerable Dee.

Like music lives, nor may that music die, Still in the far, fair Gaelic places:

The speech, so wistful with its kindly graces, Holy Croagh Patrick know, and holy Hy:

The speech, that wakes the soul in withered faces, And wakes remembrance of great things gone by.

Like music by the desolate Land's End Mournful forgetfulness hath broken:

No more words kindred to the winds are spoken, Where upon iron cliffs whole seas expend That strength, whereof the unalterable token Remains of wild music, even to the world's end. ${ }^{39}$

\footnotetext{
${ }^{36}$ Stanford, Three Poets of the Rhymer's Club, 20.

${ }^{37}$ Stanford, Three Poets of the Rhymer's Club, 20.

${ }^{38}$ Stanford, Three Poets of the Rhymer's Club, 20.

${ }^{39}$ Lionel Johnson, "Celtic Speech," Three Poets of the Rhymer's Club: Ernest Dowson, Lionel Johnson, John

Davidson, ed. Derek Stanford (Cheadle: Carcanet Press, 1974), 101-102.
} 
One of the greatest references to Celtic spirituality here is the Croagh Patrick, an Irish holy mountain said to have been visited by Saint Patrick, Ireland's patron saint, in the fifth century, as well as being a popular site for pilgrimages even today. ${ }^{40}$ Furthermore, the reference to "Holy Hy," also interpreted as "Hii," is an earlier name for the island of lona found in the work of the monk and historian Bede from the seventh century. ${ }^{41}$ Iona, as one of the Celtic islands off the coast of Scotland, also had one of the greatest Celtic monasteries. ${ }^{42}$ Perhaps even more important than its monastery, lona had once been home to Saint Columba in the sixth century, said to be able to achieve miracles -among his other miraculous powers-as well as being the subject of a popular posthumous Saint cult starting in the seventh century. ${ }^{43}$ As a Saint, Columba was the embodiment of many Celtic Christian virtues at the time: he took to poverty, deprived himself of necessities including sleep and comfort, and embraced the act of penance, even leaving lona behind while he spread the word of God. ${ }^{44}$ That Johnson includes both of these references definitely shows the impact that Celtic Christianity was having, not only as a literary revival, but as a revival amongst the population as well.

Furthermore, still within the realms of religion but branching out into a general sense of the Celtic past, Johnson's poem seems to be a call to remember that past as a valid and desirable entity. Johnson writes of many things here, among them the old Celtic music that can

\footnotetext{
${ }^{40}$ The Editors of the Encyclopaedia Britannica, "Croagh Patrick," Encyclopaedia Britannica, last modified July 2013, accessed April 21 ${ }^{\text {st }}$, 2018. https://www.britannica.com/place/Croagh-Patrick.

${ }^{41}$ See author's note of Bede, Bede's Ecclesiastical history of the English people: a revised translation, trans. and intro. A.M. Seller (London: G. Bell and Sons, 1917), 92. See also pages 140 and 181 of the same work for further references to the Island of Hii being another name for the Island of lona, as well as information about lona's monastery.

${ }^{42}$ Bradley, Celtic Christianity, 1.

${ }^{43}$ Bradley, Celtic Christianity, 17-18.

${ }^{44}$ Bradley, Celtic Christianity, 18.
} 
still be heard if one knows where to look, and the old ways of speech recognized by the Celtic saints, that "wakes the soul in withered faces." 45 The poem seems to read as both romantic and sad; romantic in that the Celtic past, in all its spiritual, lyrical, and linguistic glory, is portrayed here as idealized, perhaps even utopian. However, that these elements of the past seem to have been forgotten is where the sorrow makes itself known, especially when Johnson writes: "Mournful forgetfulness hath broken:/no more words kindred to the winds are spoken." ${ }^{46}$ Arguably however, there is hope, and the sense that we can still find traces of this once beautiful past goes hand in hand with the literary revival and the goal of bringing the Irish and Celtic pasts back to the present. Lastly, there is a touching upon of the element of nature here too, in that Johnson makes notes of the sea, the strong iron cliffs, the familial relationship to the winds, something that we have already seen is characteristic of Celtic spirituality. ${ }^{47}$

However, it is Johnson's 1894 poem, Ireland, bound in a collection called Ireland, with Other Poems, which was said to be the most prominent work for the Celtic and Gaelic revival. ${ }^{48}$ Upon reading it, there is little question as to why it would achieve such praise in this movement. Johnson writes Ireland as a very highly nationalistic and spiritual poem, in that it appears as a call to restore Ireland to the glory of its past by demonstrating that the Celtic spirit has never died in the souls of the Irish. ${ }^{49}$ "All passion, save the love of Ireland, stilled," Johnson writes, but "we sorrow not with shame,/but proudly: for thy soul is as the snow." 50 This

\footnotetext{
45 Johnson, "Celtic Speech," 101.

46 Johnson, "Celtic Speech," 102.

47 Johnson, "Celtic Speech," 102.

${ }^{48}$ Stanford, Three Poets of the Rhymer's Club, 21.

${ }^{49}$ Lionel Johnson, "Ireland," The Collected Poems of Lionel Johnson, $2^{\text {nd }}$ revised edition, ed. Ian Fletcher, (New York and London: Garland Publishing Inc., 1982), 93-98.

50 Johnson, "Ireland," 93, 94.
} 
portrays the Celtic people as defeated, yet proud, which sets the tone not only for the poem, but no doubt resonated with Celtic nationalist movements at the time. The poem itself is very long, consisting of two-hundred seventy-five lines and twenty-five verses, but there many important verses that deal with nationalism, and more importantly, the spiritual past of the Celtic Irish peoples.

The references to both God and the specific Celtic Christianity aspects in this poem are many. Saint Columba, for example, is mentioned within the same vein as nationalism; he is willing to die for his people, both for nationalism as a Gaelic or Celtic man, and spiritually, in that he was a missionary who had left lona to spread Christianity to other people: ${ }^{51}$

If death come swift upon me, it will be Because of the great love I bear the Gael! So sang upon the separating sea Columba, while his boat sped out of hail, And all grew lonely. ${ }^{52}$

A common theme in the poem, nationalism and Christianity go hand in hand again:

No swordsmen are the Christians! Oisin cried:

O Patrick! thine is but a little race.

Nay, ancient Oisin! they have greatly died In battle glory and with warrior grace.

Signed with the Cross, they conquered and they fell:

Sons of the Cross, they stand:....53

This passage does many things by weaving together mythology and religion. The story of Oisin follows that he was a warrior and a bard of Ireland, who left with a magical faery woman to the

${ }^{51}$ Bradly, Celtic Christianity, 18.

52 Johnson, "Ireland," 96.

53 Johnson, "Ireland," 95. 
Land of Youth. ${ }^{54}$ Upon his return Oisin only realizes that three hundred years have passed when he comes across the ruins of his old home, and through his travels he eventually meets Saint Patrick, who treats him with kindness and has his stories recorded. ${ }^{55}$ Also likely a reference to history, Oisin's words that Patrick's small population of Celtic people make terrible swordsmen are refuted by Johnson on nationalist and religious grounds by saying that the Celts may have been defeated, but they did so fighting for their beliefs and their God, beliefs that have never faltered. ${ }^{56}$

Furthermore, it is implied that only through this national pride and religious unity that the Irish will find their voices and take action:

Cry, mighty Dead! until the people find

Their souls a furnace of desire and scorn.

Call to the hosting upon Tara, call

The tribes of Eire all:

Trump of the Champions! immemorial Horn! ${ }^{57}$

Here, Tara is a reference to an ancient Irish burial hill, with Christian structures thought to date from between year zero to the sixth century. ${ }^{58}$ Upon reading it this way, it could mean that it is upon standing with religion and celebrating their ancient pasts that the tribes of Eire -the people of Ireland-- will find their strength within their souls to be the nation they once were.

Lastly, the poem ends with the following lines, appearing as perhaps a spoken prayer or a call to their deities due to their being italicized:

\footnotetext{
${ }^{54}$ Rolleston, Myths and Legends, 270-271.

${ }^{55}$ Rolleston, Myths and Legends, 275-276.

56 Johnson, "Ireland," 95.

57 Johnson, "Ireland," 97.

58 The Editors of the Encyclopaedia Britannica, "Tara," Encyclopaedia Britannica, last modified January 2018, accessed April 22 ${ }^{\text {nd }}, 2018$. https://www.britannica.com/place/Tara-hill-Ireland.
} 


\begin{abstract}
O Rose! O Lily! O Lady full of grace!
o Mary Mother! O Mary Maid! hear thou.

Glory of Angels! Pity, and turn thy face,

Praying thy Son, even as we pray thee now,

For thy dear sake to set thine Ireland free:

Pray thou thy little Child!

Ah! who can help her, but in mercy He?

Pray then, pray thou for Ireland, Mother mild!

O Heart of Mary! pray the sacred Heart:

His, at Whose word depart

Sorrows and hates, home to Hell's waste and wild. ${ }^{59}$
\end{abstract}

This last verse quite obviously makes many appeals to both God and the Virgin Mary, with the hope, Johnson's hope perhaps, that religion could be what 'saves' Ireland. Much like the previous verse extract, there is a very direct line connecting freedom, nationalism, and religion; the possible idea present that Ireland could not exist without this relationship. Ultimately, this poem says a lot about Irish Celtic Christian beliefs, including both pre-Christian and mythology, and is presented as a very strong piece of literature that supports the Celtic and Irish movements.

Not all literature of the time was completely pro-Celtic, however. Matthew Arnold, for example was a Victorian Englishman who seemed to try and take a middle ground when it came to his support. A professor and literary critic, his great work is the 1867 publication, The Study of Celtic Literature, a compilation of four written lectures that he gave while acting as the Chair of Poetry in Oxford.$^{60}$ As the title implies, Arnold discusses many of the contemporary issues

\footnotetext{
59 Johnson, "Ireland," 98.

${ }^{60}$ Matthew Arnold, The Study of Celtic Literature, 1970 edition (Port Washington, N.Y, and London: Kennikat Press, 1867.), v.
} 
surrounding the Celtic peoples of his day, especially on literature, with sometimes conflicting opinions.

On the one hand, Arnold saw positives to the Celtic movement. England needed the qualities of the Celt, Arnold argued, and he had much to say to about the merits of the Celtic spirit. ${ }^{61}$ The Celtic peoples, whether they were Welsh or Irish, were more humane, more intelligent, and more gracious that the average Englishman, things that Arnold believed were sorely missing in the beings of his fellow Saxon brothers, as he frequently liked to refer to them. ${ }^{62}$ He especially respected the Eisteddfod festival that he went to in Wales, a culture and tradition festival that sought artistic and poetic talents, and also made sure to emphasize the Celtic traditions of old. ${ }^{63}$ This festival also showed "something spiritual," in the Celts, Arnold wrote, which once again was something he appreciated as being so unique to the Celts, yet he also seemed troubled that England could not achieve this level of spirituality. ${ }^{64}$

On the other hand, however, while Arnold appreciated the Celtic spirituality and national pride of the past, he did not make a strong case for it to continue. For Arnold, the Celtic Revival was getting in the way of what Arnold deemed to be more important: unity between the Irish and English. ${ }^{65}$ This involved a number of things, including the discontinuation of Welsh -one of the Celtic languages-- as it was deemed not a practical language, and the assimilation of the Celtic peoples into the greater English imperial plan. ${ }^{66}$ Ultimately, this unity

\footnotetext{
${ }^{61}$ Arnold, The Study of Celtic Literature, $x$.

${ }^{62}$ Arnold, The Study of Celtic Literature, xix.

${ }^{63}$ Arnold, The Study of Celtic Literature, 5-6.

${ }^{64}$ Arnold, The Study of Celtic Literature, 9.

${ }^{65}$ Arnold, The Study of Celtic Literature, 10.

${ }^{66}$ Arnold, The Study of Celtic Literature, 10.
} 
would be for the greater benefit of everyone, Arnold argued, even though it appeared that the Celtic peoples would be the only ones making the sacrifices necessary for this unity.${ }^{67}$ One gets the sense that the English, it appears, could continue to stay on the path they always had; there was nothing wrong with them that needed to change.

So what was his compromise? Arnold believed that much of the Celtic people's strengths lied in their pasts, so instead of trying to become their own people now, they should focus on only who they were in the past: their traditions, their spirituality, and their ways of life. ${ }^{68}$ For one, they should focus on what he calls the Science of Origins; all of society could benefit if the Celts put their energy into this, and as an old people the Celts were more qualified than others to study how they came to be: their customs, their literature, their language. ${ }^{69}$ For another, he specifically mentions that there is much to be learned from Celtic literature, and it is there that the Celtic people best express themselves as a distinct people, no doubt in part through spirituality and traditions. ${ }^{70}$ He does specifically mention a few sources: The Historic Tales of Ireland, and The Annals of the Four Masters by saying they include many important things like founding dates for churches, battle records, land and sea expeditions (some missionary work, perhaps?), important visions, and that the books are important for ecclesiastical history, among other things. ${ }^{71}$

Arnold does not specifically mention Celtic Christianity, but from what we've understood the nature of Celtic Christianity to be from this paper, it is highly twined together

\footnotetext{
${ }^{67}$ Arnold, The Study of Celtic Literature, 10.

${ }^{68}$ Arnold, The Study of Celtic Literature, 13.

${ }^{69}$ Arnold, The Study of Celtic Literature, 13-14.

${ }^{70}$ Arnold, The Study of Celtic Literature, 20.

${ }^{71}$ Arnold, The Study of Celtic Literature, 24-25.
} 
with Celtic life and identity. When Arnold argues about traditions, doubtlessly he's including religion in that sphere as well. However, Arnold sees this as something that should be preserved, but should stay in the past or practiced in inconsequential manners, just like the speaking of Welsh, for example. ${ }^{72}$ There are no practical applications for continuations of these traditions and behaviors in his desire for unity between the Celts and English. ${ }^{73}$

In conclusion, the Celtic Revival, especially in literature, was an influential and popular topic, especially in the 1880 s and 1890s of the Victorian era. Firstly, William Butler Yeats' poetry, including To Ireland in the Coming Times, and Irish Tales, dealt with Yeats' love for Ireland, both nationally and spiritually, and included the Celtic themes of nature and religion. Secondly, though not an Irishman, Rhymer's Club member Lionel Johnson wrote poems that perhaps were even more Celtic in nature than Yeats. Johnson's poems, Celtic Speech especially, was highly influenced by the holy places and saints of Ireland, including lona and the mountain of Croagh Patrick. Thirdly, Matthew Arnold held a different view, one that seemed to suggest that he believed Celtic Christianity was only a thing of the past and that in order to really have a revival as a valid entity, the Irish needed to come together with the English to achieve common goals. There were other factors involved in the literary revival, nationalism being one of them as we have seen, but Celtic Christianity was such a large influence in the lives of the Celts that it is impossible to talk of a literary revival happening without that overarching factor of religion: a combination of both the pagan and Christian Celtic religions.

\footnotetext{
72 Arnold, The Study of Celtic Literature, 10, 13.

${ }^{73}$ Arnold, The Study of Celtic Literature, 10-11.
} 


\section{Bibliography}

Arnold, Matthew. The Study of Celtic Literature, 1970 edition. Port Washington, N.Y, and London: Kennikat Press, 1867.

Bede. Bede's Ecclesiastical history of the English people: a revised translation. Revised Translation with Introduction, Life and Notes by A.M. Seller. London: G. Bell and Sons, 1917. Ebook.

Bradley, Ian. Celtic Christianity: Making Myths and Chasing Dreams. Edinburgh: Edinburgh University Press, 1999.

Green, Miranda. The Gods of the Celts. Gloucester: Alan Sutton, 1986.

Johnson, Lionel. "Celtic Speech." In Three Poets of the Rhymer's Club: Ernest Dowson, Lionel Johnson, John Davidson. Selected and Introduced by Derek Stanford, 101-102. Cheadle: Carcanet Press, 1974.

Johnson, Lionel. "Ireland." In The Collected Poems of Lionel Johnson. Second and revised edition. Edited by lan Fletcher, 93-98. New York and London: Garland Publishing Inc., 1982.

Mackey, James P. "Introduction: Is There a Celtic Christianity?” In An Introduction to Celtic Christianity. Edited by James P. Mackey, 1-21. Edinburgh: T\&T Clark, 1995.

McMahon, Timothy G. Grand Opportunity: The Gaelic Revival and Irish Society, 1893-1910. Syracuse, New York: Syracuse University Press, 2008.

Rolleston, T.W. Myths and Legends Series: Celtic. London: Bracken Books, 1985.

Schmidt, Richard H. God Seekers: Twenty Centuries of Christian Spiritualties. Grand Rapids, Michigan: William B. Eerdmans Publishing Company, 2008.

The Editors of the Encyclopaedia Britannica. "Croagh Patrick." Encyclopaedia Britannica. Last modified July 2013. Accessed April 21st, 2018. https://www.britannica.com/place/Croagh-Patrick.

The Editors of the Encyclopaedia Britannica. "Ireland." Encyclopaedia Britannica. Last modified April 2018. Accessed April 21 $1^{\text {st }}$, 2018. https://www.britannica.com/place/Ireland.

The Editors of the Encyclopaedia Britannica, "Tara." Encyclopaedia Britannica. Last modified January 2018. Accessed April 22nd, 2018. https://www.britannica.com/place/Tara-hillIreland. 
Welch, Robert. Irish Writers and Religion. Edited by Robert Welch. Gerrards Cross, Buckinghamshire: Colin Smythe, 1992.

Williams, Daniel G. "Celticism." In Oxford Twenty-First Century Approaches to Literature: Late Victorian Into Modern. Edited by Laura Marcus, Michele Mendelssohn, and Kirsten E. Shepherd-Barr, 69-82. Oxford: Oxford University Press, 2016.

Yeats, William Butler. “Dedication To 'Irish Tales.'” In The Book of the Rhymer's Club. London: Elkin Matthews, 1892.

Yeats, William Butler. "To Ireland in the Coming Times." In Selected Poems and Four Plays of William Butler Yeats. $4^{\text {th }}$ edition. Edited and with a New Foreword and Revised Introduction and Notes by M.L. Rosenthal. New York: Scribner Paperback Poetry, 1996.

Yeats, William Butler. The Celtic Twilight. Introduction by Kathleen Raine. Gerrards Cross, England: Colin Smythe Limited, 1981. 